\title{
Legal Aspect of Prohibition of Registering a Trademark Essentially Similar to the Registered Trademark
}

\author{
F Y Sitepu, S L Andriati \\ Law Program, Universitas Sumatera Utara, Medan, Indonesia \\ faradila.yulistari@usu.ac.id
}

\begin{abstract}
Trademark is one of the intellectual property rights developing rapidly in Indonesia, both viewed from the aspect of its regulation and from the community's appreciation for it. The modes of violating a trademark has shifted, from furtive violations to blatantly falsifying or imitating famous and well reputable trademarks. However, such blatant violations are committed through applying for a trademark registration. This, therefore, has led to the increasing number of dispute cases over trademark cancellation lawsuits in Commercial Courts in various regions of Indonesia, due to the argument that the applied trademark is essentially similar to a famous trademark or a previously registered trademark.In conclusion, from the lawsuits of trademark cancellation due to having essentially similar trademark to a registered or famous trademark, it is found that the application of the provisions of Article 6 paragraph (1) a and b of Law Number 15 of 2001 in a court decision is quite varied in defining the criteria of "essentially similar" and the criteria of "famous trademark". The implementation of prohibition on registering a trademark because of being essentially similar with a registered or a famous trademark is distinguished between a good-faith-based and a bad-faith-based application.
\end{abstract}

Keywords: Trademark, Famous Trademark, Essentially Similar

\section{INTRODUCTION}

Trademark is one of the intellectual property rights developing rapidly in Indonesia, both viewed from the aspect of its regulation and from the community's appreciation for it. In relation to the development of the function and meaning of trademark, Casavera [1] states that changes in trademark law in several countries (including Indonesia) have implications for the strong status of the trademark as one of the intellectual property forms that gets legal protection. Well-known trademarks with positive image are believed to provide a number of benefits, including higher customer's satisfaction and loyalty, customer's willingness to pay premium prices, customer's willingness to recommend the trademark to others, greater repurchase rates, future potential cash flow sources (through the possibility of trademark extension and trademark license) and so on.

Moreover, among modern society including the Indonesian people, a trademark is currently becoming one of the symbols of social status. This is marked by the people's growing interest to buy famous and well reputable branded products, not only among the upper middle income people but also among low-income people, and, not infrequently, some 
of them force to buy famous branded products for the sake of "prestige". As a result, even though they cannot afford the original branded products, the counterfeit or imitative ones also become the target. Consequently, in the Indonesian consumer society, the terms "ori" referring to "original" branded products and " $\mathrm{kw}$ " standing for "quality" referring to non-original branded products are currently growing.

The modes of violating a trademark have shifted, from furtive violations to blatantly falsifying or imitating famous and well reputable trademarks. However, such blatant violations are committed through applying for registeringa trademark which is substantially similar or identical with a famous trademark or a trademark registered by a good faith. This, therefore, has led to the increasing number of disputes over trademark cancellation lawsuits in Commercial Courts in various regions of Indonesia, due to the argument that the applied trademark is substantially similar with a famous trademark or a previously registered trademark.

\section{METHOD}

The approach method used in this research was a normative legal approach, a method that refers to the prevailing legal norms. The data were secondary data consisting of (a) primary legal materials in the form of legislation; (b) secondary legal materials in the form of writings, either books or articles containing comments or analysis relating to the subject matter; (c) tertiary legal materials in the form of dictionaries. The data were collected using literature reviews and document analysis. The data were analyzed using a qualitative method based on a deductive reasoning.

\section{RESULT and DISCUSSION}

\subsection{Definition and Criteria of "Substantially Similar"}

The term "Substantially Similar" arises when two "apparently" similar trademarks are compared. Practically, such comparison often becomes a problem when a certain trademark is considered to violate another. Law Number 15 of 2001 concerning Trademarks does not clearly regulate the term "Substantially Similar" in detail which makes the cases of trademark infringement remain unresolved. Judges do not have the same perception on it, as described above [2].

The elucidation section, particularly the elucidation of article 6 paragraph (1a) of the Trademark Law only defines "substantially similar" as: Similarity caused by the presence of prominent elements between one Trademark and another, which may give rise to an impression that there are similarities in terms of form, position, writing style or combination of elements or identical speech sounds contained in those two trademarks.

Based on the explanation, "substantially similar" is a "similarity". The Monolingual Indonesian Dictionary published by Balai Pustaka translates "similarity" derived from the root "similar" as "almost alike or identical". Thus, in the context of "substantially similar", such trademarks are only "almost alike" or "identical" in form, so they are not "exactly" or "equally complete" similar.

The similarity between one trademark and another is due to the presence of prominent elements of each of the compared trademarks. The prominent elements, summarized from the content of article 1 number 1 of Law concerning Trademark definition, may consist of: name, word, letters, numbers, colors arrangement, and Combination of the previous elements. 
The similarity between a trademark and a registered trademark occurs because one of the elements (name, word, letters, numbers, arrangement of colors, or a combination of all) is prominent. To what extent these elements are said to be prominent is not mentioned in the elucidation of Article 6 paragraph (1) because it only mentions that the following elements form, position, writing style or combination of elements or identical speech sounds - give rise to the "impression" of similarity.

A registered trademark is a trademark that has been registered in the Directorate General of Intellectual Property Rights [3]. A registered trademark has a legal protection, so in the event of fraudulent cases, such as imitation causing loss to the trademark that has been registered earlier, can be followed up to the Court to penalize the imitators.

Thus, in the term "substantially similar", similarity is substantial, even though those trademarks are not exactly alike, but the differences are still traceable. Thus, the similarity arising from those trademarks is merely "impression". In this context, there is no complete similarity between the trademarks, but based on the general view, they have "similar impression". To measure precisely to what extent those brands have the similar "impression", it is necessary for the elements to be further explored because law concerning trademark does not clearly elaborate the extent to which the "similar impression" can be measured visually, conceptually and phonetically.

According to Pattishall, et alin "Trademarks and Unfair Competition Fifth Edition", factors that can be used as a measuring tool to determine the existence of Substantially Similar are: (1) Similarity of Appearance, (2) Foreign Terms, (3) Similarity of Connotation, (4) Word and Picture Marks, and (5) Similarity of Sound [4].

Simply, Substantially Similar arises because of the similarities in terms of form, meaning and sound of the Compared Trademarks. The form consists of the form of words, names, letters, numbers, colors or combinations of all. The definition of meaning in this context can be extended to include the whole type of meaning, the meaning of a word with its image representation and the use of foreign terms with the same meaning [5].

\subsection{Factors Causing the Increasing Number of Cases of Trademark Cancellation Lawsuits due to the Issue of Substantially Similar with a Registered or Famous Trademark}

There are a large number of cases of trademark cancellation lawsuits due to the issue of substantially similar with a trademark that has been registered earlier or with a famous trademark Such cases occur because a certain trademark registered at the Directorate General of Intellectual Property Rights, Ministry of Justice and Human Rights, is claimed to have substantial similarity with a previously registered trademark or with a famous trademark by the owner of the registered or famous trademark.

According to Purwaningsih [6], a trademark has the following functions: (1) Distinguishing function, i.e. distinguishing the product from another company's product; (2) Reputation guarantee function, i.e. serving as the mark of the product origin, personally linking the reputation of the branded product with its manufacturer, and providing quality assurance; (3) Promotion function, i.e. serving as a means of introducing new products and maintaining the reputation of old products as well as dominating the market; (4) Investment stimulus and industrial growth function, i.e. serving to support the industrial growth through investment, both foreign and domestic investment in facingthe free market mechanism.

In addition to its distinguishing function, Sudaryat et. alargue that a trademark also functions to introduce the company and its identity. By mentioning the name of the trademark, 
people can easily identify the company being talked about, together with its reputation (good or excellent). This means that consumers can identify the company's trading activities [7].

Since the trademark protection system adopted by Law Number 15 of 2001 concerning Trademark is constitutive, only do registered trademarks have legal protection. But on the other hand, such legal protection system also illustrates that the increasingly symptomatic culture of fraudulent competition has come into the business actors.

Many factors probably cause the increasing number of cases of trademark cancellation lawsuits due to the issue of substantially similar with a trademark that has been registered earlier or with a famous trademark. To identify the factors leading to such cases, this study uses a legal system theory proposed by Lawrence M. Friedman that includes legal substance, legal structure and legal culture.

One of the benchmarks of an assessment of whether a Trademark Examiner has been working properly and professionally or indefinitely is its decision to grant or to deny a Trademark application under the assumption that smaller number of trademark cancellation lawsuits means the Trademark Examiner has relatively worked properly. On the contrary, if there are a large number of trademark cancellation lawsuits, the level of professionalism of the Trademark Examiner is still low.

Based on the exploration on the court's decisions in the Trademark cases, it is found that there isa fairly large number of trademark cancellation lawsuits filed by registered trademark or famous trademark owners on the grounds of having substantial similarity with other registered trademarks or famous trademarks.

This finding indicates that the professionalism of the Trademark Examiner in the Directorate General of Intellectual Property Rights in conducting the examination of the Trademark Application is very weak. Moreover, when carefully observed, those canceled trademarks generally have a fairly prominent similarity. Some of them are even entirely similar with the previously registered trademark or with the famous trademark, and both of the trademarks are in the same class and type of products.

\section{CONCLUSION}

It is concluded that the factors leading to the increasing number of cases of "substantially similar" are legal substance, legal structure and legal culture. Regarding the trademark cancellation lawsuits on the grounds of having substantial similarity with other registered trademarks or famous trademarks, it is found that the implementation of the provisions of Article 6 paragraph (1) a and b of Law Number 15 of 2001 in the court decision concerning the criteria of "substantially similar" and the criteria of "famous trademark" is relatively varied. The implementation of a prohibition of te registeringa trademark on the grounds of having substantial similarity with other registered trademarks or famous trademarks is distinguished between a good-faith-based application and a bad-faith-based application.

The provisions concerning the prohibition of registering a trademark which hassubstantial similarity with another previously registered trademark contained in Article 6 paragraph (1) a and $b$ of Law Number 15 of 2001 need to be expanded in terms of their applicable power:from the same kind of goods and/or services to the same class of goods and/or services. This is intended to restrict the intention of the applicants to share, imitate or trace the popularity of a famous trademark with agood reputation. 


\section{REFERENCES}

[1] Casavera, Delapan Kasus Sengketa Merek di Indonesia. Yogyakarta: Penerbit Graha Ilmu, 2009.

[2] I. B. Maulana, Sukses Bisnis Melalui Merek Patendan Hak Cipta. Bandung: Citra Aditya Bakti, 1997.

[3] M. R. D. Djumahana, Hak Milik Intelektual Sejarah Teori dan Prakteknya di Indonesia. Bandung: Citra Aditya Bakti, 1993.

[4] I. B. Maulana, Kompilasi Undang-Undang Hak Cipta, Paten, Merek, dan Terjemahan Konvensi-Konvensi di Bidang Hak Atas Kekayaan Intelektual. Bandung: Citra Aditya Bakti, 2005.

[5] J. Rahmi, Hak Kekayaan Intelektual Penyalahgunaan Hak Eksklusif. Surabaya: Airlangga University Press, 2007.

[6] E. Purwaningsih, Perkembangan Hukum Intellectual Property Rights Kajian Hukum Terhadap Hak Atas Kekayaan Intelektual dan Kajian Komparatif Hukum Paten. Bogor: Ghalia Indonesia, 2005.

[7] S. Sudaryat and R. R. Permata, Hak Kekayaan Intelektual Memahami Prinsip Dasar, Cakupan, dan Undang-undang Yang Berlaku. Bandung: Penerbit Oase Media, 2010. 